\title{
The conservation status of the birds of Negros, Philippines
}

\author{
THOMAS M. BROOKS, TOM D. EVANS, GUY C. L. DUTSON, \\ GUY Q. A. ANDERSON, DESIDERIO C. ASANE, ROBERT J. TIMMINS \\ and ANGELA G. TOLEDO
}

\section{Summary}

Ornithological surveys were carried out in the remnant forests of the island of Negros, in the central Philippines, over five weeks in the summer of 1991 . From this work it is concluded that, without the implementation of immediate conservation measures, the global extinction of four bird species is likely to occur in the near future. These are Negros Fruit-dove Ptilinopus arcanus, Negros Bleeding-heart Gallicolumba keayi, Writhed-billed Hornbill Aceros waldeni and White-throated Jungle-flycatcher Rhinomyias albigularis. Another four species restricted to the lowlands of Negros and the adjacent island of Panay, Visayan Tarictic Hornbill Penelopides panini, White-winged Cuckoo-shrike Coracina ostenta, Flame-templed Babbler Stachyris speciosa and Visayan Flowerpecker Dicaeum (australe) haematostictum, must be considered under extreme threat, and the endemic Negros Striped-babbler Stachyris nigrorum is under considerable pressure. A further twelve species listed as globally threatened are also in serious danger of extinction on Negros. This paper details the results of fieldwork and presents our conclusions and suggestions for conservation, which must include the direct preservation of the last fragments of lowland forest on the island.

\section{Introduction}

The Cambridge Philippines Rainforest Project 1991, a student expedition (see Evans et al. in prep.), assessed the importance of a number of remnant forests for designation as reserves under the proposed Integrated Protected Areas System (IPAS). Five out of ten weeks of fieldwork were spent on the island of Negros, with the other five being spent on Mindoro (Dutson et al. 1992) and Siquijor (Evans et al. in press). Fieldwork was undertaken in four of the patches of forest remaining on Negros: Mt Mandalagan, Mt Canlaon, Ban-ban in central Negros and the Balinsasayao-Mt Talinis massif (see Figure 1).

The deforestation which has so seriously affected the entire country has been particularly devastating in the central Philippines. In recent years, population pressures and subsequent clearance for cultivation in the uplands have become the primary cause of forest degradation.

The central Philippine islands of Negros, Panay, Guimaras, Masbate and Ticao comprise the Western Visayas faunal region (McGregor 1920), to which the small islands of Tablas, Romblon and Sibuyan are sometimes added (e.g. Delacour and Mayr 1946). Delacour and Mayr also included Cebu and Siquijor in the group, but these islands are generally taken as the Central Visayan faunal region (McGregor 1920). In a global overview of all such centres of biodiversity, 


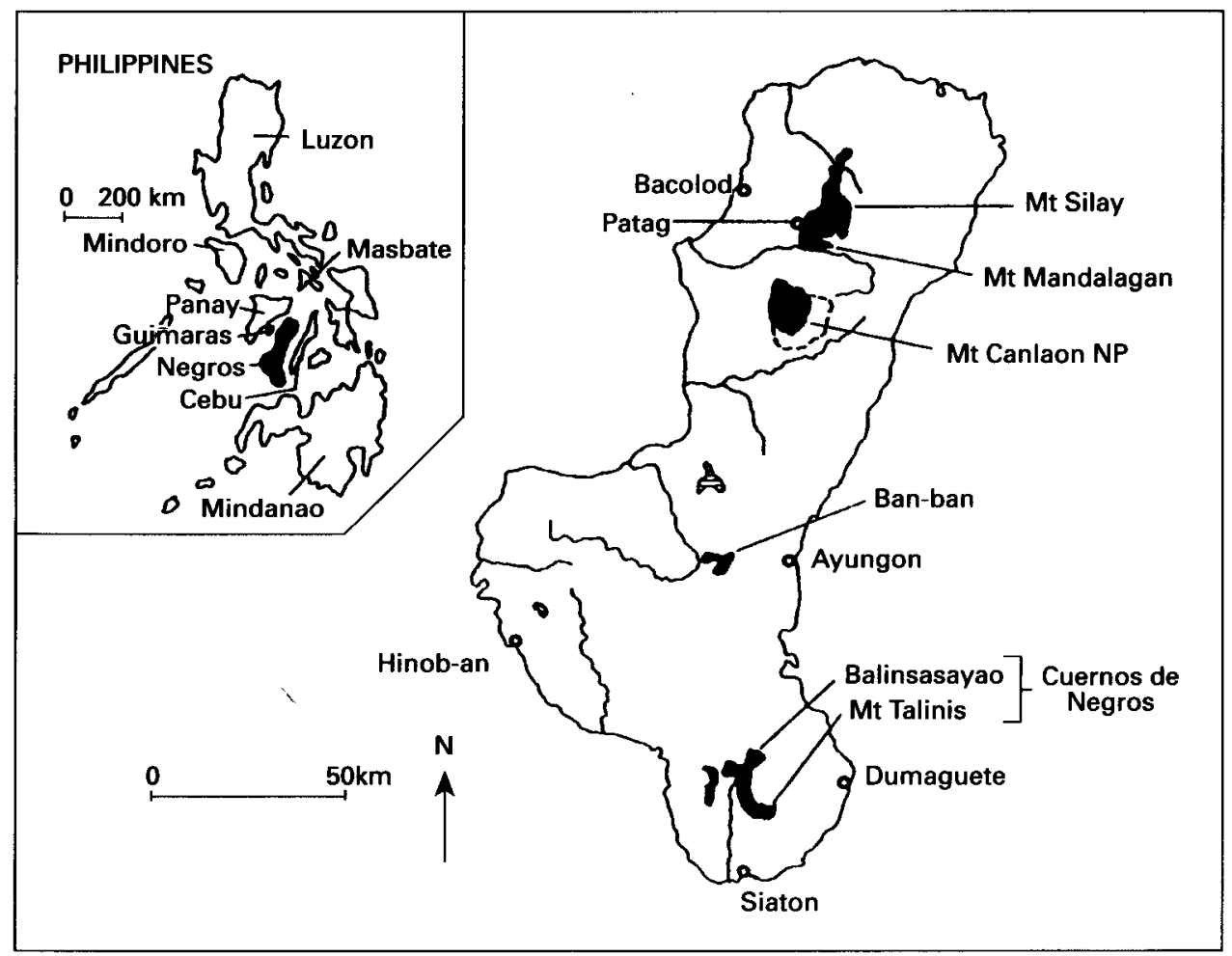

Figure 1. Map of Negros showing forest cover. Forest cover is based on maps produced by SSC (1988), modified according to the results of this survey. Shaded areas are those visited during fieldwork. Hatching indicates other forest areas shown on SCC (1988) but not visited by this survey. A dashed line indicates a National Park boundary.

ICBP (1992) identified 221 "Endemic Bird Areas" (EBAs), of which nine are in the Philippines. The conservation priority of the EBAs was assessed by two criteria relating to biodiversity and threatened status of species. The Western Visayas scored the highest ranking for both criteria, along with only 11 of the other 220 EBAs.

Three species of birds - Negros Fruit-dove Ptilinopus arcanus, Negros Bleeding-heart Gallicolumba keayi and Negros Striped-babbler Stachyris nigrorum - are considered endemic to Negros. Following recent taxonomic reassessment (Kemp 1988, Sibley and Monroe 1990), and as a result of deforestation over their former ranges, a further six seem likely to be effectively restricted to Negros and Panay. There is a tenth species, Panay Striped-babbler Stachyris latistriata, restricted to Panay.

If current rates of deforestation continue, it is predicted that Negros Fruitdove Ptilinopus arcanus, Negros Bleeding-heart Gallicolumba keayi, Writhed-billed Hornbill Aceros waldeni and White-throated Jungle-flycatcher Rhinomyias albigularis will be extinct within the next couple of decades; indeed, it is possible that Ptilinopus arcanus is already extinct. The other five species now restricted to 
Negros or to Negros and Panay - Visayan Tarictic Hornbill Penelopides panini, White-winged Cuckoo-shrike Coracina ostenta, Flame-templed Babbler Stachyris speciosa, Negros Striped-babbler S. nigrorum and Visayan Flowerpecker Dicaeum (australe) haematostictum - are also highly threatened in global terms. A further twelve species listed in Collar and Andrew (1988) are resident on the island, and all of these are in danger of local extinction.

Birds are widely used to indicate the status of the rest of an area's fauna. The imminent extinction of nine species from Negros implies comparable losses in other groups, and hence a major reduction in biodiversity. It is therefore stressed that conservation action in this region should be given utmost priority.

\section{Forest cover in the Western Visayas}

Few parts of the tropics have been as seriously deforested as the Western Visayas. Only $5.7 \%$ of the region's original forest cover remains (SSC 1988), and much of this is montane and mossy forest above $1,000 \mathrm{~m}$. Masbate and Guimaras are both effectively 100\% deforested (SSC 1988, Oliver et al. 1991, M. Ebreo verbally 1991) (Tables 1 and 2).

Table 1. Forest cover $\left(\mathrm{km}^{2}\right)$ in 1987 (SSC 1988)

\begin{tabular}{lcccrr}
\hline Forest type & Closed canopy & Open cariopy & Mangrove & Mossy & Total forest \\
\hline Negros & $\mathbf{1 4 8}$ & 373 & 10 & 17 & 548 \\
Panay & 261 & 738 & 24 & - & 1,023 \\
Masbate & - & - & 175 & - & 17 \\
Romblon group & - & $\mathbf{1 9 5} 940$ & $\mathbf{1 , 4 9 4}$ & $\mathbf{2 , 4 5 5}$ & $\mathbf{7 1 , 0 4 2}$ \\
Philippines & $\mathbf{2 4 , 3 4 2}$ & & & \\
\hline
\end{tabular}

Table 2. Forest cover as a percentage of land area (SSC 1988)

\begin{tabular}{lcc}
\hline & Total land area $/ \mathrm{km}^{2}$ & \% Forest cover \\
\hline Negros & 13,328 & 4.11 \\
Panay & 12,172 & 8.41 \\
Masbate & 4,048 & 0.01 \\
Romblon group & 1,356 & 0.15 \\
Philippines & 295,381 & 24.05 \\
\hline
\end{tabular}

Historically, the islands were covered in lowland dipterocarp forest, a habitat much exploited for its valuable timber. By the 1950s, however, the bulk of the forest below $750 \mathrm{~m}$ had been cleared and the timber exported via the port of Cebu. In the mid-1970s a ban on commercial logging was introduced in Philippine provinces with less than $40 \%$ forest cover remaining. This led to the termination of the logging concessions at Ban-ban and Balinsasayao on Negros. However, despite the efforts of the Philippine government's Department of the Environment and Natural Resources (DENR), clearance of forest for agriculture (known as kaingin in the Philippines) and through small-scale logging continues apace. Should this rate of deforestation continue, it is predicted that soon virtually no forest will remain on Negros below 1,00o m. 
The small island of Guimaras has been entirely cleared (M. Ebreo verbally 1991). The island of Sibuyan accounts for the bulk of the forest remaining in the Romblon group, a large proportion of which is mossy and closed-canopy forest (R.J.T. pers. obs. 1992). It must be noted that the accuracy of the figures in the tables is questionable: Panay retains considerable amounts of mossy forest (M. Ebreo and P. Gonzales verbally 1991) and the Swedish maps fail to show the Balinsasayao area as retaining forest cover.

\section{Previous ornithological fieldwork on Negros}

The birds of Negros were extensively collected in the late nineteenth and early twentieth centuries, as summarized in Dickinson et al. (1991). The inter-war period saw little ornithological fieldwork on the island, but studies were restarted there between 1947 and 1967 by D. S. Rabor, A. L. Rand and S. D. Ripley. Their collections included Balinsasayao in 1951 (Rand 1951, Rand and Rabor 1952) and 1952-1953 (Rand 1954), and Mt Canlaon in 1953 (Ripley and Rabor 1956). Other published records include Rabor (1954) and Ripley and Rabor (1955). Rabor has since collected at Balinsasayao once again (Rabor et al. 1970), and the area has also been collected in by Alcala and Carumbana $(1975,1980)$. M. Ebreo carried out some fieldwork on Mt Canlaon in about 1980 (verbally 1991).

Birdwatchers have visited the island six times in the last decade: B. F. King (1983), M. Turton, G. Speight and R. Rowland (1986), J. Hornskov and S. Jensen (1987), F. R. Lambert (in litt. 1989), T. H. Fisher and ourselves. All but Hornskov and Jensen and ourselves visited Mambucal only. Erickson and Heideman (1983), incidental to their work on bats, caught some birds in a year's mistnetting at Balinsasayao.

\section{Sites surveyed in 1991}

The expedition visited Negros between 19 July and 27 August. Six study-sites were visited (Table 3), covering the four largest forest blocks of the six indicated on recent land-cover maps (produced by SSC 1987).

Table 3. Coverage of the study-sites

\begin{tabular}{llccc}
\hline Site & \multicolumn{1}{c}{ Dates } & $\begin{array}{c}\text { Man-hours } \\
\text { in forest }\end{array}$ & $\begin{array}{c}\text { Mist-netting } \\
\text { hours (18 m nets) }\end{array}$ & $\begin{array}{c}\text { Altitudinal range of } \\
\text { forest visited /m }\end{array}$ \\
\hline Guintubdan & 19 July -29 July & 116 & 773 & $800-2,300$ \\
Mambucal & 30 July -7 Aug & 211 & 486 & $750-2,300$ \\
Mt Mandalagan & 9 Aug -14 Aug & 80 & - & $600-1,100$ \\
Ban-ban & 16 Aug-19 Aug & 87 & - & $600-900$ \\
Balinsasayao & 20 Aug-24 Aug & 87 & - & $700-1,200$ \\
Mt Talinis & 26 Aug & 19 & $600-1,400$ \\
Total & 35 fieldwork days & 600 & 1,259 & \\
\hline
\end{tabular}

This figure is given as a gauge of effort at each site, to be used in conjuncton with the Appendix. The unit taken is time spent in forest, with multiple observers working together counting as a single observer. 
A range of other techniques was used to supplement direct observation and mist-netting. Quantitative analysis of population densities was carried out at Guintubdan and Mambucal using the standard line-transect method as used in the Philippines by Jensen (in prep.). Analyses of the results of these surveys can be found in Evans et al. (in prep.). A small amount of night-torching was carried out using a Nitech X-cell torch and Petzl headtorches, but this method was unproductive on Negros. Mammals were surveyed through bat-netting and direct observation. Discussion with local people, especially those making use of the forest, such as hunters and kaingineros (shifting cultivators), was an integral part of fieldwork. The situation in each forest block was also discussed before and after fieldwork with local DENR officials.

Extremely little forest remains on Negros below $800 \mathrm{~m}$ : stands at Mambucal and at Ban-ban were the only significant areas located. Small areas may also be found around mid-mountain forest edge (similar to the degraded patch visited near Patag), and possibly also at Hinob-an and Siaton (see Figure 1). These low-altitude areas are particularly important for birds of special conservation interest.

\section{Description of sites}

\section{Mt Canlaon National Park}

Two sectors of the park-Guintubdan in the south-west and Mambucal in the north-west-were visited for a total of 19 days. Mt Canlaon $(2,546 \mathrm{~m})$ has a long history of ornithological coverage. However, its national park status has not protected the lower slopes from total clearance. On the east slope of the mountain no forest reportedly occurs below 1,200-1,300 $\mathrm{m}$ (the area is known locally as "the salad bowl"); on the west it has retreated to around $1,000 \mathrm{~m}$ in most areas, with only one sector, Mambucal, still reaching down to $750 \mathrm{~m}$.

When this lowest block of forest at Mambucal is lost, as it will be in a few years if the current intensity of cutting and clearance continues, the only suitable habitat for five of the park's rarest birds (Blue-crowned Racquet-tailed Parrot Prioniturus discurus, Visayan Tarictic Hornbill, White-winged Cuckoo-shrike, Flame-templed Babbler and White-throated Jungle-flycatcher) will be lost, and with it much of the value of the national park.

Immediate action is necessary to prevent drastic impoverishment of this area, a candidate IPAS site and one of the most important forests left in the Visayas. If illegal destruction is stopped by enforcement of the law, the future of the forest should be assured.

Guintubdan, south-west sector, Mt Canlaon National Park Forest along the valley of the Guintubdan trail starts at $1,050 \mathrm{~m}$, and is then continuous up to the bare peak of the volcano at $2,500 \mathrm{~m}$. It descends somewhat lower on adjacent ridges, but is in poor condition at these altitudes. Ten years ago the forest boundary was around $800 \mathrm{~m}$ where only fragments now remain. This indicates a fast rate of retreat and a great loss of important mid-altitude forest.

The slopes are suffering extensive clearance for agriculture. The forest is used 
for rattan- and orchid-gathering and the hunting of larger animals (e.g. pigs and pigeons). Agriculture now extends for an estimated $2 \mathrm{~km}$ inside the park boundary.

Mambucal, north-west sector, Mt Canlaon National Park Forest descends to about $750 \mathrm{~m}$ in this area, lower in some precipitous valleys. A handful of forest species were recorded in parkland at Mambucal village, at around $400 \mathrm{~m}$. On the gentler slopes it has been logged up to around $950 \mathrm{~m}$, above which the forest is primary and extends to the summit at $2,500 \mathrm{~m}$. The logged forest is rather open, but many large trees remain, and the area supports a high diversity and density of forest birds.

The lower portions are being cleared for agriculture, charcoal production and lumber extraction, with these activities being aided by an earth road into the forest. The cutting of tree-ferns, rattans and canes was noted. Butterfly- and beetle-collecting was particularly intensive and possibly a threat to endemic butterfly species. Collection of other insects, snails, parrots and the hunting of larger mammals were observed. All these activities are much in need of regulation by permit and wardening. This area should be the focus of any increased government activity in the national park.

\section{Patag, north slope of Mt Mandalagan}

Fairly extensive primary and secondary forest remains on the slopes of the mountain. This habitat is heterogeneous, owing to the many steep-sided gorges and ridges in the area. It descends to $700 \mathrm{~m}$ on steep valley sides, where it is very broken, and to around $850 \mathrm{~m}$ on gentler slopes. No survey work was performed above $1,100 \mathrm{~m}$, but it appeared that more primary forest exists between there and the peak at 1,500 m. Extensive areas of the steep slopes are, however, not forest, but rather covered by grasses, tree-ferns and scrub.

A number of small residual blocks of secondary forest also survive beyond the forest edge, though they will soon all be cleared. The patch around Patag village supported a number of important bird species, although only a few hectares in extent and heavily degraded. Further areas of steep, broken-canopy forest and scrub persist on the walls of larger gorges down to $600 \mathrm{~m}$, but could not be adequately surveyed.

Owing to the steepness of slopes, kaingin is encroaching the mountain forest at a slower rate than elsewhere on Negros, but many areas have nevertheless been logged. Two well-worn trails into the area are used to transport rattan and timber. Attempts are being made to enhance the value of the natural forest for future logging by removing climbers and non-commercial tree species.

The conservation status of the area is unclear. The mountain forest around the scenic "sulphur springs" may be a national park but no indication exists locally. The residual patches have no protected status.

Note: Mt Silay This forest, until recently linked to but now isolated from Mt Mandalagan, could not be visited on military advice, owing to severe insurgency problems. The local government offices suggested around 3,00o ha of forest 
remains, apparently all above $950 \mathrm{~m}$ on the outside of the crater, but descending lower in the central valley. The area has been logged, and is likely to support a similar avifauna to Mt Mandalagan. It has not been visited by ornithologists. The large area of forest remaining here makes the site a priority for investigation.

\section{Ban-ban, Ayungon municipality}

The forest is a collection of hilltop remnants around one large valley near Banban between $600 \mathrm{~m}$ and $900 \mathrm{~m}$ altitude. Most of the area was logged under concession until 1979, and illegal logging has continued since. Small stands of primary forest with a closed canopy remain, situated with substantial areas of secondary forest, many areas of which are being recleared for kaingin. There are also large areas of second-growth scrub and grass, with many standing dead trees.

Logging and clearance for kaingin are aided by the gentle terrain and allweather roads. Hunting is also intensive here. Large stands of natural forest are being enriched for future logging, much as on Mt Mandalagan. The area is designated a Watershed Protection Forest.

\section{Cuernos de Negros}

As detailed below, the highlands in the south of Negros still hold a considerable area of forest at mid-altitude and high altitude and have most, if not all, of the species of conservation interest. It seems likely that the insurgency-troubled and remote western side of the massif has more low-altitude forest, and this should be a priority for future surveys. The massif would make an excellent site for protection by the IPAS scheme, rivalling Mt Canlaon, which appears to lack two of the rarest species (Aceros waldeni and Stachyris nigrorum) and is badly degraded at low altitudes.

The Swedish Space Corporation land-cover maps (SSC 1987) are inaccurate for these sites, which lie in different parts of one forest block. There is still forest on all sides of the Twin Lakes at Balinsasayao, and in a broad zone around them, which is not mapped.

Balinsasayao Relief is generally steep, with fresh and abandoned fields in most flatter parts of the area, within and surrounding the remaining forest. Forest ran from $750 \mathrm{~m}$ to $1,200 \mathrm{~m}$, the highest point locally. The big, buttressed trees typical of lowland forest appear only at the lower fringes of the remaining forest. The area has been logged.

Commercial logging was probably not a contemporary problem in the area we surveyed. The area is a catchment forest, and a local government reforestation project is run from a bunkhouse there. The staff say that some illegal kaingineros have already been evicted from within the forest. However, reforestation is not taking place on the cleared land beyond the forest boundary but on the remaining lowland forest, where strips or blocks of undergrowth are cleared to replant with seedlings of commercially desirable (mostly 
fast-growing) species. This is likely to have a great impact on forest structure here, particularly if the subsequent commercial logging implied by these activities occurs.

Mt Talinis (Valencia Geothermal Site) It was only possible to spend one day at this site, reaching no higher than $1,400 \mathrm{~m}$. It is only a few kilometres from Balinsasayao and forest is still continuous between the two, but it shows some important differences and merits individual attention.

The high peaks of Cuernos de Negros (Mt Talinis) are still covered with primary mid-mountain and mossy forest. Lower down on the Valencia side, which we visited, the continuous forest descends to $1,100 \mathrm{~m}$. There are degraded patches on steep slopes down to $850 \mathrm{~m}$. The forest is primary but clearance for agriculture has been extensive in the valleys and on some hillsides, reaching $1,300 \mathrm{~m}$, higher than anywhere else we visited.

The whole area is under the jurisdiction of the Philippine National Oil Corporation (PNOC), which has a large geothermal power plant lower down the mountain. PNOC have a legal responsibility to prevent any further destruction of forest here, especially considering the site's high conservation value and its importance as a watershed. However, the roads they police allow free access for a large number of kaingineros, who have devastated the forest at lower altitudes and are penetrating deep into the remaining primary forest. Hunting and snaring occurs, also the collection of canes, rattans and tree-ferns. The large tract of forest above 1,200 $\mathrm{m}$ extending around the head of the valley towards Balinsasayao appears to have no protection except its remoteness.

\section{Species accounts of threatened birds}

\section{Negros Fruit-dove Ptilinopus arcanus}

Historical status Known only from a single specimen and a sighting of a second individual at 1,250 $\mathrm{m}$ on Mt Canlaon in 1953 (Ripley and Rabor 1955).

Expedition records $P$. arcanus was not recorded in this survey, despite nine days being spent at the type-locality and a further 11 days at other sites in the same range of mountains.

Current status Although the type-specimen was taken at 1,250 $\mathrm{m}$, the species may have been chiefly lowland in distribution, in which case it may well be extinct since no forest survives below $750 \mathrm{~m}$ in northern Negros. Even if it could survive in the highlands, all pigeons and fruit-doves are hunted on Mt Canlaon, and its survival may have been jeopardized by this.

It has been suggested that an alternative explanation for the lack of records could be the possible invalidity of the species: "Ptilinopus arcanus", considering its small size and atypical plumage, may have been a runt specimen of Yellowbreasted Fruit-dove $P$. occipitalis or of a green-pigeon Treron sp., but a verdict has been postponed until the male is described (Mayr 1957). 
Negros Bleeding-heart Gallicolumba keayi

Historical records Historically uncommon on Negros (Dickinson et al. 1991). The last record was of a single bird in lowland forest near San Carlos in north-east Negros in 1927.

Expedition records Only one bird was recorded during the expedition fieldwork: flushed off the ground by a single observer at $900 \mathrm{~m}$ above Mambucal, Mount Canlaon. Despite the brief views, the description obtained precludes the two potential confusion species, Common Emerald-dove Chalcophaps indica and White-eared Brown-dove Phapitreron leucotis, the bird having generally warm brown upperparts with a greyish head and tail, short broad rounded wings and some white on the underparts. In size the bird was maybe just larger than $C$. indica. Local reports of the species were obtained at Mambucal and Patag, although it was said to be very rare at both sites.

All known records of G. keayi are from lowland forest. The allospecific Luzon Bleeding-heart $G$. luzonica has only occasionally been recorded up to 1,000 $\mathrm{m}$ on Luzon (T. H. Fisher verbally 1991). It is not known whether G. keayi tolerates secondary forest, but the lack of reports from Ban-ban suggests that perhaps it does not.

At both Mambucal and Patag it was claimed that G. keayi was occasionally trapped, which may have a significant effect on such a scarce species.

Current status The apparently low densities of this species, combined with the pressures of deforestation, trapping and hunting, justify its place in the Red Data Book. G. luzonica is said to be able to survive in poor secondary forest, second growth and plantations (T. H. Fisher verbally 1991), but there is little of even this habitat left on Negros. G. keayi should be viewed as Endangered, the highest category of threat.

\section{Nicobar Pigeon Caloenas nicobarica}

Historical status Listed in McGregor (1910) for Negros.

Expedition records No records or reports of this species were obtained during fieldwork in the Philippines.

Current status C. nicobarica has not been recorded in the Western Visayas for many years. This species feeds in lowland forest and breeds most commonly on small undisturbed islands. It appears that very few such islands remain in the Philippines and there is nowhere suitable for feeding on Negros. Overpopulation in coastal areas is bringing the species's habitat under increasing pressure, with the associated increases in hunting as observed elsewhere in its range (Collar and Andrew 1988). One possible site is the tiny island of Apo, just off the south of Negros. 


\section{Philippine Cockatoo Cacatua haematuropygia}

Historical status McGregor (1910) included Negros among the many islands for which this species is listed. C. haematuropygia was presumably fairly common and widespread on Negros, as across the rest of its range, until the turn of the century, but has declined rapidly since then. No records can be found for Negros since 1896 (Ogilvie Grant 1896). There are no recent reports from Panay.

Expedition records C. haematuropygia was not recorded or reported in our 36 days of fieldwork on Negros. By contrast, on Mindoro many local people were aware of the "white parrots", even though only a handful of pairs remains. The species is heavily trapped throughout its range for the pet trade (Lambert 1992). Its absence from Negros can be compared with our similar failure to record any large parrots Tanygnathus spp. on the island: both Blue-naped $T$. lucionensis and Blue-backed T. sumatranus are known from Negros, T. lucionensis as recently as 1977 (Dickinson et al. 1991). It is quite possible that all three are extinct on the island.

Current status Despite the extent of its historical range, $C$. haematuropygia now only survives in any numbers on Palawan, Luzon and Mindanao (e.g. T. H. Fisher verbally 1991, Lambert 1992). It has been effectively extirpated from the Western and Central Visayas over the last 20 years, and is globally Endangered.

\section{Visayan Tarictic Hornbill Penelopides panini}

Taxonomic status We follow recent workers who have split Tarictic Hornbill $P$. panini into several full species, including the Visayan form, which is also, confusingly, known as P. panini (Kemp 1988, Sibley and Monroe 1990). There are two subspecies within this form, their new names being $P$. p. panini and $P$. p. ticaensis. Sibley and Monroe (1990) name the Visayan forms "Tarictic Hornbill", but we propose "Visayan Tarictic Hornbill" for clarity, since Tarictic Hornbill was the original name for the whole superspecies.

Historical status The P. panini superspecies (comprising eight taxa) was historically widespread and common in forest up to $1,000 \mathrm{~m}$ throughout the Philippines (Dickinson et al. 1991). P. p. panini is known from Negros, Panay and Guimaras, from Pan de Azucar and Sicogon, two tiny islands off north-east Panay (Alcala and Sanguila 1969) and from Masbate. It has been recorded fairly regularly from Negros over the last few decades (e.g. Erickson and Heideman 1983, Hornskov and Jensen 1987). P. p. ticaensis, the only other subspecies in the new P. panini, is endemic to Ticao. On Panay, birds reportedly survived at Malayu-an, Ajoy, in small patches of forest and second growth, until hunted out in 1990 (R.J.T. pers. obs.) but there are no other recent reports. There are no recent reports from Ticao, and the island is small and almost entirely deforested (SSC 1988).

Expedition records The species was recorded at three sites on Negros. It appears to require tall forest below $1,050 \mathrm{~m}$. It was also reported at Guintubdan. The breakdown of records is shown in Table 4 . 
Table 4. P. panini records on Negros

\begin{tabular}{lcc}
\hline & Total bird-days & Composition of groups \\
\hline Mambucal & 10 & $4+4+2$ heard \\
Mt Mandalagan & 4 & $1+1+1+1$ heard \\
Balinsasayao & 6 & $4+2$ heard \\
\hline
\end{tabular}

Birds were generally recorded fairly low in the canopy, usually at forest edge or by clearings. This may be indicative of an ecological separation between this species and Writhed-billed Hornbill Aceros waldeni, as an analogous situation occurs on Sulawesi, where a Penelopides species occupies a subcanopy niche and an Aceros species is generally found in the canopy (Whitten et al. 1987). The highest altitude recorded was at $1,050 \mathrm{~m}$, at Mambucal. The call is a nasal, high-pitched trumpeting, and is not far-carrying, in contrast to many other species of hornbill.

Our encounter rate (of 0.05 birds/man-hour) here was considerably lower than at the one site on Mindoro where the allospecific Mindoro Tarictic Hornbill $P$. mindorensis was recorded. There the encounter rate was 0.29 birds/man-hour (Dutson et al. 1992): this, however, was a lowland forest site. Very little tall forest below 1,000 $\mathrm{m}$ remains on Negros aside from the sites where we recorded the species.

We had only one indication of tolerance of heavily disturbed forest: one of the Mt Mandalagan records was of a single bird in the tall forest along the stream by Patag village on 13 August. This forest is very limited in extent and could not support a viable population of the species.

Current status Only very small amounts of forest remain on Masbate, Guimaras, Ticao, Pan de Azucar and Sicogon (SSC 1988); the species has almost certainly been hunted to extinction on Sicogon (R.J.T. pers. ,obs.) and probably also on the other islands. It is rare on Negros and may be very rare on Panay.

Considering the species's habitat requirements and restricted geographical range, we recommend that it be included in the next Red Data Book, probably as Vulnerable. When its full status on Panay is known, its status may be reassessed as Endangered.

\section{Writhed-billed Hornbill Aceros waldeni}

Taxonomic status Recent texts, following Kemp (1988), have tended to treat $A$. leucocephalus leucocephalus and $A$. l. waldeni as separate species (e.g. Sibley and Monroe 1990). Dickinson et al. (1991) do not recognize this split, lumping the two forms as Writhed Hornbill $A$. leucocephalus while accepting that the differences between the two "are admittedly considerable".

Historical status A. leucocephalus is known from Mindanao, Camiguin Sur and Dinagat, and $A$. waldeni from Negros, Panay and Guimaras. A. leucocephalus is locally not uncommon on Mindanao, and is regularly reported from sites such 
as Bislig and Metondo (Clarke 1983, King 1983, Lewis 1991). The restricted historical range of $A$. waldeni, however, combined with the wholesale clearance of the forests of the Western Visayas, has put it under considerable threat. Previous to this expedition, there were no records for 80 years.

Dickinson et al. (1991) state that "Kemp (1988) erroneously said he assumed that Ben King's tape recording of waldeni was from Luzon, where neither form occurs". King did not record $A$. waldeni when he visited Negros (King 1983): it seems likely that this recording is actually of $A$. leucocephalus and is hence from Mindanao. R. S. Kennedy and P. Gonzales did not find A. waldeni during their fieldwork on Panay in 1988 (R. S. Kennedy in litt. 1992).

Expedition records Only one group was recorded, of four individuals - two males and two females or juveniles - seen twice at Balinsasayao on 18 July. Considering that a total of 87 man-hours over four days were spent in the field at Balinsasayao, it seems that the species survives at only a low density in the area. Although all large hornbills are generally low density species, encounter rates with $A$. leucocephalus on Mindanao in 1992 were much higher (R.J.T. pers. obs.).

The last scientists to conduct ornithological fieldwork at Balinsasayao were Erickson and Heideman (1983), who state that "We did not record the hornbill Aceros leucocephalus; unaware of the potential presence of a second species of hornbill, we assumed that all of our records (usually of individuals in dense foliage) were of Penelopides panini. It seems likely that both species still occur at the site". They do not give any reason for believing this, although the expedition records have vindicated their judgement.

A. leucocephalus is a lowland species (contra Dickinson et al. 1991, who state that they occur "usually above $800 \mathrm{~m}$ "), seen only in lowland and mid-mountain forest up to 1,100 $\mathrm{m}$ on Mindanao (Gibbs 1983, Lewis 1991, R.J.T. pers. obs.). Our records of $A$. waldeni, for which altitudinal records are very few, were at $950 \mathrm{~m}$. The group was initially detected both times from the call, a loud nasal "lamb-like" bleating - "wa-ha-ha" - being heard. The same area had been covered previously with no sign of the hornbills, and the group was not present the next morning.

Current status A. waldeni must be highly threatened. We recorded none in suitable habitat for the species in the north of Negros, at Mambucal or Mt Mandalagan. Reports of two species of hornbill, one "large" and one (the "tarictic") "small" were received from Patag, and if the species indeed survives either here or on Mt Silay then these will be areas vital for the preservation of the species. There are no historical records of the species from northern Negros.

$A$. waldeni may survive on Panay, although it has not been recorded on the island in recent years. Guimaras is completely deforested and the species must be assumed to be extinct there.

It may well be that the southern Negros highlands are the last forest left in the world where $A$. waldeni survives. It is of utmost priority that this forest is surveyed to ascertain the true status of the bird there. Even at the most optimistic estimate, there cannot be more than four or five sites still holding populations of the species: Cuernos de Negros, Mt Mandalagan, Ban-ban and Mt 
Baloy, Panay. We recommend that $A$. waldeni is listed in the next Red Data Book as Endangered.

\section{White-winged Cuckoo-shrike Coracina ostenta}

Historical status Widespread on Negros, Panay and Guimaras in lowland forest, becoming scarcer in montane forest with one record of a single bird at 2,150 m on Mt Canlaon in 1953 (mentioned in Dickinson et al. 1991). Recent records exist for Negros from all visitors to Mambucal (King 1983, Turton et al. 1986, Hornskov and Jensen 1987, T. H. Fisher verbally 1991, F. R. Lambert verbally 1991).

Expedition records We recorded $287 \mathrm{C}$. ostenta bird-days over six sites on Negros.

As illustrated in Table 5, C. ostenta was found to be fairly common at all non-montane sites. The lower numbers of records at Ban-ban can be accounted for by the quality of the forest: most cuckoo-shrikes require large trees (G.C.L.D. pers. obs.), and are hence scarcer in recently logged forest (such as that at Ban-ban, Patag village and Mt Talinis). The species was not found in small remnant lowland forest patches (all below $300 \mathrm{~m}$ ) on Panay (R.J.T. pers. obs.).

The species was surveyed along a $2 \mathrm{~km}$ line transect at Mambucal from $750 \mathrm{~m}$ to $1,050 \mathrm{~m}$. Detection was considered close to $100 \%$ within $10 \mathrm{~m}$ either side of the path, a strip covering $0.04 \mathrm{~km}^{2}$. In this strip an average of 1.7 birds per transect ( 39 birds in 23 transects) was noted. This suggests a density of 42.5 birds per $\mathrm{km}^{2}$. The figure should be treated as very approximate. It may not apply to other sites, and certainly not to other altitudes. However, if half the forest on Negros lies at suitable altitudes, the population may be of the order of 10,000 birds.

The records at Ban-ban indicate that $C$. ostenta can probably survive in secondary forest, albeit at lower densities, though the lack of records from a later visit to Panay suggests that smaller patches of less than 50 ha are unsuitable (R.J.T. pers. obs.). No birds were recorded above $1,100 \mathrm{~m}$, however, and it seems unlikely, despite the altitudinal range of the species given in Dickinson $e t$ al. (1991), that significant populations can survive in montane forest.

Current status $C$. ostenta is now limited to Panay and Negros: it seems very unlikely that the species survives on Guimaras. This survey shows it to be

Table 5. C. ostenta records on Negros

\begin{tabular}{lccc}
\hline & $\begin{array}{c}\text { Altitudinal range of } \\
\text { C. ostenta }(\mathrm{m})\end{array}$ & Total bird-days & Bird-days/man-hour \\
\hline Guintubdan & - & 0 & 0 \\
Mambucal & $700-1,100$ & 145 & 0.69 \\
Mt Mandalagan & $800-1,000$ & 46 & 0.90 \\
Patag village & 650 & 2 & 0.13 \\
Ban-ban & $600-900$ & 40 & 0.46 \\
Balinsasayao & $800-1,100$ & 53 & 0.61 \\
Mt Talinis & 950 & 1 & 0.05 \\
\hline
\end{tabular}


moderately common in good forest below $1,100 \mathrm{~m}$ on Negros, and there is no reason to believe that this is not also true on Panay. The species seems able to adapt in some degree to larger areas of poor-quality forest, and may also be able to survive in the lower portions of montane forest.

However, the restricted geographical and altitudinal range of the species must mean that its total world population is very small, and continued clearance of Negros and Panay will lead to its extinction. We consider it to be Vulnerable.

\section{Flame-templed Babbler Stachyris speciosa}

Historical status Known from throughout Negros, and recently discovered on Panay (Dickinson et al. 1991). It was historically fairly common in lowland (below $1,000 \mathrm{~m}$ ) forest, forest edge and second growth across Negros (Dickinson et al. 1991). Most ornithologists visiting Mambucal in recent years have recorded the species. Erickson and Heideman (1983) caught it at Balinsasayao.

Expedition records Overall 78 S. speciosa bird-days were recorded over three sites in north and central Negros (Table 6). Of these, 20 were records of the species's distinctive descending 12-note song of thrush-like quality, a recording of which was obtained. A further four birds were mist-net captures (of which one was trapped three times), from which a series of photographs, biometrics and other details was obtained (Evans et al. in prep.).

It seems that $S$. speciosa depends on forest with thick undergrowth below $1,100 \mathrm{~m}$ altitude. Very little primary forest remains on Negros (or Panay) at such altitudes, and even second growth is being cleared at a rapid rate. Many of the birds recorded were singles, often located singing. Others, usually in groups of up to three, were seen in mixed-species flocks, foraging in the undergrowth and in understorey bushes and trees or in dense growths of vines and ferns on larger trees. The majority of birds stayed in deep cover, and were unobtrusive unless singing.

No birds were recorded at Guintubdan or on Mt Talinis, where most forest surveyed was above the species's altitudinal range. Surprisingly, no birds were recorded in the similar forest at Balinsasayao, although Erickson and Heideman (1983) netted the species here nine times in 4,836 (assuming that their nets were open for twelve hours each day) net-hours. Birds were occasionally seen in second growth at Ban-ban as well as in forest.

The highest densities of S. speciosa that we found on the island were in the thick undergrowth of the degraded secondary forest around the village of Patag. $S$. speciosa also presumably persists in the lower fringes of forest on Mt Man-

Table 6. S. speciosa records on Negros

\begin{tabular}{lccc}
\hline & $\begin{array}{c}\text { Altitudinal range of } \\
\text { records }(\mathrm{m})\end{array}$ & Bird-days & Bird-days/man-hour \\
\hline Mambucal & $750-1,050$ & 51 (ind. 6 netted) & 0.24 \\
Patag village & $600-650$ & 17 & 0.59 \\
Ban-ban & $600-800$ & 10 & 0.11 \\
\hline
\end{tabular}


dalagan, which were only briefly visited. We suspect that it is also present in forest patches around Mt Talinis and Mt Silay. It was not found within degraded and secondary lowland forest in four sites on Panay (R.J.T. pers. obs.). The dearth of records from Panay suggests that a large proportion of this island is unsuitable; possibly it is a mid-mountain bird.

The species was surveyed on Mt Canlaon along a $2 \mathrm{~km}$ transect running from $750 \mathrm{~m}$ to $1,050 \mathrm{~m}$. It was considered that detection was reasonably high within $10 \mathrm{~m}$ of the path, a strip of $0.04 \mathrm{~km}^{2}$. Twenty birds were noted on 23 transects within this strip, implying a density of 22 birds per $\mathrm{km}^{2}$. This figure is highly approximate. No extrapolation to total population can be attempted in view of the higher densities in secondary forest, whose extent is unknown.

Current status As with C. ostenta, continued clearance of the lower altitudes of forest remaining on Negros will lead to the extinction of $S$. speciosa in the near future, although it seems to be able to survive in some heavily degraded forest. We recommend that it be considered Vulnerable.

\section{Negros Striped-babbler Stachyris nigrorum}

Historical status Endemic to Negros, and known only from the Cuernos de Negros massif. The type-specimen was collected in 1952 on Mt Talinis (Rand and Rabor 1952), and the species has been recorded by several ornithologists visiting the mountain range since.

Expedition records S. nigrorum was recorded only on Mt Talinis, the typelocality, above the Valencia geothermal power station. Only one day (26 August) was spent at this site, from ogh 30 to $17 \mathrm{~h} 30$, between $950 \mathrm{~m}$ and $1,400 \mathrm{~m}$ altitude.

During this time a total of 76 individual $S$. nigrorum were recorded, all above $1,050 \mathrm{~m}$, making this the second most frequently recorded species at the site (after Mountain White-eye Zosterops montanus). S. nigrorum was one of the primary constituents of mixed feeding-flocks, along with $Z$. montanus, Mountain Leaf-warbler Phylloscopus trivirgatus, Blue-headed Fantail Rhipidura cyaniceps and Philippine Bulbul Hypsipetes philippinus. Most were observed feeding in the foliage of understorey trees. A single juvenile was recorded, being fed by an adult. Identification on call was not difficult: a soft and continuous "tsip, tsip . . .". A single burst of song, "tu-tu, tutu soo", was also heard.

Despite the proximity of Mt Talinis to our study site at Balinsasayao, we failed to find $S$. nigrorum there, and it was not reported by Erickson and Heideman (1983). This is presumably because of the species's preference for midmountain and mossy forest, for the highest peak above Balinsasayao barely reaches $1,200 \mathrm{~m}$.

Current status $S$. nigrorum is still common on Mt Talinis. It is perhaps found throughout the higher areas of the rest of the Cuernos de Negros massif, which still retains considerable forest cover. The species inhabits higher-altitude forest than many rare species. Furthermore, it was seen in recently degraded forest, agriculture and logging activities having reached 1,250 $\mathrm{m}$ on Mt Talinis, higher 
than any other site we saw on Negros. Although not under threat in the next few years, the potential habitat for the species is contracting.

There is only one record of $S$. nigrorum away from the south Negros highlands, of "some birds" seen at high altitude on Mt Canlaon (Hornskov and Jensen 1987). Despite much ornithological coverage of Mt Canlaon, there have been no other records there. It may therefore be that the species, along with several other Philippine congeners, is effectively a single-mountain endemic. Nevertheless, it is probably the least threatened of the Red Data Book species of Negros, and its ability to survive in high-altitude forest should preserve it into the next century. However, no data on population density above $1,400 \mathrm{~m}$ is available, and its habitat will be eroded if clearance continues at the present rate. The species should be treated as Vulnerable.

\section{White-throated Jungle-flycatcher Rhinomyias albigularis}

Taxonomic status Vaurie (1952) lumped $R$. albigularis with a similar Bornean form into White-browed Jungle-flycatcher $R$. gularis. However Wolters (1980) and Dickinson et al. (1991) treat it as a full species, on the basis of its plumage differences, dependence on lowland forest and disjunct distribution.

Historical status According to Dickinson et al. (1991) it is uncommon in lowland and mid-mountain forest understorey. No records of the bird can be found for any altitudes above $900 \mathrm{~m}$.

There are no recent records of the species from Guimaras, and only two from Negros: both Turton et al. (1986) and Hornskov and Jensen (1987) recorded single birds at Mambucal on Mt Canlaon. F. R. Lambert did not record the species in two days at Mambucal in 1989 (verbally 1991).

Expedition records The expedition recorded a single group, at Ban-ban. There were one adult and two juveniles, in sparse understorey of tall secondary forest at $600 \mathrm{~m}$ altitude. All three were seen on two consecutive days (22 and 23 August).

The birds were extremely quiet, elusive and difficult to see. All three spent most of the time perched on branches 1-8 $\mathrm{m}$ above the forest floor, occasionally flitting off to flycatch or move to another perch. The juveniles often sat together, and only associated loosely with the adult. The birds were between Mountain Verditer-flycatcher Eumyias panayensis and White-vented Whistler Pachycephala homeyeri in size and structure, with clean white but poorly defined throats, white bellies and vents, pale buff breasts and medium-brown underparts. All had slightly darker lores and ear-coverts, giving the birds a subtle dark mask. The juveniles had clear pale tertial fringes and greater- and median-covert bars: these were considerably duller on the adult, which was in tail moult. Calls were very quiet and limited to a short, disyllabic "tse-tsip", rising slightly, and to a continuous "sip-sip-sip . . .". A brief chatter similar to Eumyias panayensis was also occasionally heard. The song was thin and quiet, reminiscent of Snowybrowed Flycatcher Ficedula hyperythra.

All observers noted the similarity between the birds and $P$. homeyeri, but 
eliminated the species on the throat patch, tertial- and covert-fringes, dark mask, plumper structure and call. Further potential confusion lies with Ashybreasted Flycatcher Muscicapa randi, which was not seen during the expedition. Skins of this species were compared to those of $R$. albigularis at the British Museum, Tring, where the latter did show a well-marked throat cut-off as depicted in DuPont (1971). Nevertheless, $M$. randi was eliminated on a number of features, notably pale remige fringes, short bill, pale lower mandible, overall greyness and considerably smaller size. Furthermore, like other juvenile Muscicapa spp., juveniles of $M$. randi show extensive scaling on the upperparts.

Current status $R$. albigularis may well be the most threatened species recorded by the expedition. No forest remains on Guimaras, and, considering its requirement for tall, deeply shaded forest below $900 \mathrm{~m}$, the potential habitat for the species on Negros is extremely limited.

It was recorded on the lower forest margins at Mambucal in 1986 and 1987, by two different groups of observers. Neither spent more than four days on $\mathrm{Mt}$ Canlaon. The expedition covered the lowest remaining forest at Mambucal for a week, including 486 net-hours of mist-netting, but did not record the species. Considering the rate of forest retreat at Mambucal, it seems likely that $R$. albigularis is now locally extinct.

It seems unlikely that the forest at Ban-ban will last more than a few years without immediate action being taken. $R$. albigularis should be treated as Endangered with imminent global extinction.

\section{Ashy-breasted Flycatcher Muscicapa randi}

Taxonomic status $M$. randi is a recent split (e.g. Dickinson et al. 1991) from the widespread Asian Brown Flycatcher M. dauurica (formerly M. latirostris), which is a rare winter visitor to the Philippines.

Historical status It is known from Luzon and Negros only, with no published records on Negros since 1877 . There are a couple of recent records of the species from Luzon, from Angat Dam (T. H. Fisher verbally 1992) and from the Sierra Madre (A. Jensen verbally 1991, T. H. Fisher verbally 1992).

Expedition records We did not record $M$. randi during our fieldwork on Negros.

Current status $M$. randi is a lowland forest species, occurring below $1,200 \mathrm{~m}$ (Dickinson et al. 1991). It has not been recorded on Negros for over a century. In an overview of the conservation status of birds on Luzon, Jensen (in prep.) treats $M$. randi as globally Endangered, and the failure of our expedition to record it on Negros would support this conclusion.

Celestial Monarch Hypothymis coelestis

Historical status McGregor (1910) listed Negros amongst the six islands from which this species was then known: it has since also been reported from Samar. 
The last record of the Negros and Sibuyan race $H$. c. rabori was collected at Basay, Bayawan, Negros Oriental, by D. S. Rabor in December 1959 (Dickinson et al. 1991).

\section{Expedition records None.}

Current status There have been no records of $H$. coelestis from Negros since 1959. Only a handful of birds have been seen elsewhere in the last decade, mainly on Luzon (T. H. Fisher verbally 1991, F. R. Lambert verbally 1991), and the species appears to be on the brink of global extinction.

\section{Visayan Flowerpecker Dicaeum (australe) haematostictum}

Taxonomic status This taxon has previously been considered the West Visayan subspecies of Red-keeled (= Philippine) Flowerpecker, D. australe haematostictum. Sibley and Monroe (1990) and Dickinson et al. (1991) lump the form, although the latter suggest field studies to resolve its taxonomy. It should be noted that the Mindoro endemic $D$. retrocinctum is a member of the australe superspecies and that haematostictum may well be taxonomically closer to retrocinctum than it is to australe. The specific status of retrocinctum has never been questioned and it would seem sensible to treat all three taxa as either subspecies or full species. Based on the following field observations of all three taxa (australe only on Luzon and Mindanao), we suggest that all are worthy of specific status.

(1) All are basically glossy blue-black above and off-white below with patches of bright blood-red plumage. Plumage differs considerably as follows. In australe a narrow red stripe runs from the breast to the lower belly, varying to a small extent in both length and width but never approaching that of haematostictum; the rest of the underparts are grey, excepting a white throat and, on a few individuals (seen on Mindanao), a narrow white border to the red. In haematostictum the red extends over most of the lower breast and belly but not the flanks, the upper border is outlined with a thick black stripe, the flanks and throat are white, and the lower belly and vent are paler grey than on australe. In retrocinctum there are three red patches: on the belly (a little more than on australe), on the chin and upper throat, and a small half-collar; the upper border of the belly patch is outlined in black, this extending as a widening stripe onto the head, encompassing the other two red patches, while the remaining pale areas on the underparts are intermediate in shade between australe and haematostictum.

(2) Vocal differences were apparent in the field but need recording and formalizing.

(3) There are no intermediate subspecies.

It should be noted that juveniles of all three taxa are probably inseparable in the field. Plate 82 in DuPont (1971) erroneously depicts a flowerpecker without any red in its plumage as a female australe. 
Historical status Listed by McGregor (1920) for Negros, Guimaras and Panay. It was considered common on Negros in the 1950 s in forest, scrub and plantations (Rabor 1977). It was recorded on Mt Canlaon by Turton et al. (1986).

Expedition record We recorded surprisingly few birds, considering the historical status of the species on Negros and the abundance of $D$. australe on Luzon and of $D$. retrocinctum on Mindoro (Dutson et al. 1992). Birds were seen in forest at Guintubdan $(1,250 \mathrm{~m}$ ), in gardens at Mambucal resort (400 $\mathrm{m}$ ), in the scrub around Patag village $(600 \mathrm{~m})$, and at Balinsasayao $(850 \mathrm{~m})$. The expedition recorded 21 bird-days, with the majority of those being in the scrub remaining around Patag and Mambucal villages.

This paucity of records could be in part accounted for by the large number of flowerpeckers which went unidentified at each site (although all well-seen flowerpeckers were identified). However, it is likely that the proportions of birds identified will still provide a fairly accurate picture of the relative abundance of flowerpeckers on Negros. Hence our ratios of nine Bicoloured Flowerpeckers $D$. bicolor and 23 Orange-bellied Flowerpeckers $D$. trigonostigma to each $D$. haematostictum can be taken as an indication of the scarcity of the species. Conversely, we recorded seven $D$. haematostictum for each Pygmy Flowerpecker D. pygmaeum, and no Striped Flowerpeckers $D$. aeruginosum were seen during our time on Negros.

Current status The taxon may well be threatened, and should be classed as Indeterminate until its status on Panay is known. It was recorded at several lowland sites visited on Panay in 1992 (R.J.T. pers. obs.). D. australe is a lowland species (although we recorded D. a. haematostictum up to $1,250 \mathrm{~m}$ on $\mathrm{Mt}$ Canlaon), and while it can survive well in second growth little of even this habitat remains anywhere on Negros.

\section{Green-faced Parrotfinch Erythrura viridifacies}

Historical status E. viridifacies is known historically from Luzon, and was collected in Negros Oriental, at Nagoro, Siaton (Rabor et al. 1970). There have been no other Negros records. E. viridifacies is described as "uncommon in forest, especially in bamboo, probably above 1,000 $\mathrm{m}$, but apparently occasionally irrupts into the lowlands" (Dickinson et al. 1991).

Expedition records Much of our fieldwork was spent in forest around $1,000 \mathrm{~m}$, but the species was not recorded.

Current status Parrotfinches are notoriously local and erratic in abundance, so failure to record $E$. viridifacies despite conducting much fieldwork within its preferred habitat does not necessarily indicate that the species has been lost from Negros. A small patch of forest is shown near Siaton on the Swedish Space Corporation forest-cover maps (1988): it is important that this is visited by researchers as soon as possible in order to ascertain the status of the species 
on the island. No recent records are known from Luzon (T. H. Fisher verbally). It should probably be treated as Indeterminate.

\section{Near-threatened species}

The following species resident on Negros were proposed by Collar and Andrew (1988) for "near-threatened" status:

Malayan Night-heron Gorsachius melanolophus A highly secretive species, feeding by forest streams, which we failed to record. Likely to be highly threatened on Negros, or extinct.

Philippine Hawk-eagle Spizaetus philippensis Four individuals were recorded on Negros: two on Mt Canlaon, at $900 \mathrm{~m}$ and 1,290 m; one at Balinsasayao at $900 \mathrm{~m}$; and one on Mt Talinis, at 1,000 m. S. philippensis may be unobtrusive and occurs at low densities throughout its Philippine range, but the paucity of records compared to other forest raptors on Negros and other islands (R.J.T. pers. obs.) suggests that its status should be reviewed. Dickinson et al. (1991) state that the species is restricted to lowland and mid-mountain forest, and it must be under considerable threat on Negros considering the small amount of such habitat that remains. It may be better considered Vulnerable.

Tabon Scrubfowl Megapodius cumingii Not recorded during our fieldwork. The species is extremely secretive, but we received local reports from two sites: $\mathrm{Mt}$ Mandalagan and Ban-ban. It is likely to come under severe pressure from hunting and egg-collecting throughout the Philippines (Dickinson et al. 1991). $\mathrm{M}$. cumingii is also found in Sulawesi, where it is commoner but still declining (Rozendaal and Dekker 1989, Andrew and Holmes 1990).

Spotted Imperial-pigeon Ducula carola This endemic was unrecorded in our fieldwork in the Philippines. Whilst it is a fairly low-density species, it is not necessarily restricted to the lowlands, reaching up to 2,000 $\mathrm{m}$ (Dickinson et al. 1991), although it is likely that such high-altitude records are of daily moving birds.

Blue-crowned Racquet-tailed Parrot Prioniturus discurus This was found to be fairly common in the lower margins of forest at Mambucal (up to $900 \mathrm{~m}$ ) and at Ban-ban (to $850 \mathrm{~m}$ ). Surprisingly, no birds were recorded on Mt Mandalagan or in the highlands of southern Negros, although there was at least as much apparently suitable habitat at these sites as there was at Ban-ban. We recorded a total of $98 \mathrm{P}$. discurus bird-days on Negros, of which 89 were at Mambucal. The species is found throughout the Philippines and it seems unlikely to be under immediate threat of extinction, unless trapping pressure increases.

Rufous-lored Kingfisher Halcyon winchelli A lowland forest species, occurring only below $750 \mathrm{~m}$ (Dickinson et al. 1991). It is quite possible that the species is extinct on Negros. 
Spotted Wood-kingfisher Actenoides lindsayi This bird is found in primary and secondary forest on Luzon (race lindsayi) and Negros (race moseleyi). Although, like all Actenoides species, $A$. lindsayi is an unobtrusive mid-storey species, we recorded six bird-days on Negros (plus another three in six days of field observation on Luzon, at Mt Makiling and Angat Dam). Of the Negros records, four were of two birds netted twice each, one at Guintubdan (at 1,250 m), one at Mambucal (at $850 \mathrm{~m}$ ). The other two were of a bird in dense scrub in the gardens in Mambucal resort (at $400 \mathrm{~m}$ ) and of a bird in the secondary forest beside the old logging road at Balinsasayao (at $850 \mathrm{~m}$ ). These records suggest that $A$. lindsay $i$ is able to tolerate a degree of habitat disturbance.

Rufous Paradise-flycatcher Terpsiphone cinnamomea This is a lowland forest specialist occurring at low population densities throughout the Philippines (Dickinson et al. 1991). A single bird was recorded in a mixed-species flock at $700 \mathrm{~m}$ at Ban-ban. The species is presumably very rare on Negros but is probably not under immediate threat of global extinction considering its extensive range.

\section{Subspecies endemic to the Western Visayas}

Whilst conservation interest tends to focus on full species, subspecific taxa also contribute to biological diversity. There are a large number of subspecies endemic to the Western Visayas (see Dickinson et al. 1991), the majority of which are found on Negros (Table 7). Considering the high level of subspecific endemism of Negros, the conservation of the island's forests is highly significant in the preservation of genetic diversity.

Table 7. Subspecies endemic to the Western Visayas

\begin{tabular}{lll}
\hline Species & & Known range \\
\hline Small Buttonquail & Turnix sylvatica nigrorum & Negros \\
Amethyst Brown-dove & Phapitreron amethystina maculipectus & Negros \\
Philippine Scops-owl & Otus megalotis nigrorum & Negros \\
Philippine Frogmouth & Batrachostomus septimus menagei & Negros and Panay \\
Spotted Wood-kingfisher & Actenoides lindsayi moseleyi & Negros \\
Coppersmith Barbet & Megalaima haemacephala intermedia & Western Visayas \\
Plain-headed Rhabdornis & Rhabdornis mystacalis rabori & Negros \\
White-browed Shortwing & Brachypteryx montana brunneiceps & Negros \\
Island Thrush & Turdus poliocephalus nigrorum & Negros \\
Mountain Verditer-flycatcher & Eumyias panayensis panayensis & Negros and Panay \\
Snowy-browed Flycatcher & Ficedula hyperythra nigrorum & Negros \\
Flaming Sunbird & Aethopyga flagrans daphoenonota & Negros \\
Flaming Sunbird & Aethopyga flagrans guimarensis & Panay and Guimaras \\
Bicoloured Flowerpecker & Dicaeum bicolor viridissimum & Negros and Guimaras \\
Mountain White-eye & Zosterops montanus pectoralis & Negros \\
\hline
\end{tabular}

If the Northern Visayas (i.e. Masbate, Romblon, Sibuyan, Tablas and Ticao) are included within the Western Visayas faunal region, the following subspecies found on Negros can also be taken as endemic to the region: Philippine Hanging-parrot Loriculus philippensis regulus, White-bellied Black Woodpecker Dryo- 
copus javensis philippensis, Greater Flameback Chrysocolaptes lucidus xanthocephalus, Bar-bellied Cuckoo-shrike Coracina striata panayensis, Philippine Bulbul Hypsipetes philippinus guimarensis, Philippine Oriole Oriolus steerii nigrostriatus, Elegant Tit Parus elegans albescens, White-browed Shama Copsychus luzoniensis superciliaris, Blue-headed Fantail Rhipidura cyaniceps albiventris (with a further race, $R$. c. sauli endemic to Tablas), Celestial Blue Monarch Hypothymis coelestis rabori, White-vented Whistler Pachycephala homeyeri winchelli, Orange-bellied Flowerpecker Dicaeum trigonostigma dorsale and Golden-yellow White-eye Zosterops nigrorum nigrorum.

It is likely that the population of Flame-templed Babbler Stachyris speciosa recently discovered on Panay will be described as a new subspecies (Dickinson et al. 1991). Visayan Tarictic Hornbill Penelopides panini also occurs as two subspecies within the faunal region; the Masbate subspecies may be extinct.

Whilst the majority of these subspecies are forest residents and will come under increasing threat in the next couple of decades, only $P$. a. maculipectus, L. p. regulus, C. l. superciliaris and H. c. rabori and the subspecies of $S$. speciosa and $P$. panini are in immediate danger of extinction. Note that the two subspecies of Loriculus philippensis endemic to Cebu and Siquijor are already thought to be extinct (Parkes and Dickinson 1991). O. m. nigrorum, A. l. moseleyi, M. h. intermedia, C. s. panayensis, O. s. nigrostriatus, $R$. $m$. rabori and the two races of $A$. flagrans are also probably under significant threat.

\section{Status of other forest birds on Negros}

Of the 190 species of resident birds of Negros, 110 were recorded in our fieldwork. Failure to find some of the other 80 can be directly accounted for by the fact that effectively all fieldwork was carried out in forest, with only opportunistic observations in marshland and coastal habitats. However, 32 forest-dependent species were not recorded, of which eight are threatened or nearthreatened and discussed above.

Of the remaining 24, two raptors (Barred Honeybuzzard Pernis celebensis and Crested Goshawk Accipiter trivirgatus) are unobtrusive and occur at low densities. Four forest nightbirds - Philippine Scops-owl Otus megalotis, Brown Hawkowl Ninox scutulata, Great Eared-nightjar Eurostopodus macrotis and Philippine Nightjar Caprimulgus manillensis - were not heard calling: they may be seasonal callers, and no tape-lures were available. Amethyst Brown-dove Phapitreron amethystina, Black-chinned Fruit-dove Ptilinopus leclancheri and Hodgson's Hawk-cuckoo Cuculus fugax were not recorded, possibly because of their unobtrusive habits.

However, failure to record the other 14 forest-dependent species gives some indication as to their status on the island. Pompadour Green-pigeon Treron pompadora, Green Imperial-pigeon Ducula aenea and Pied Imperial-pigeon $D$. bicolor are all lowland species (Dickinson et al. 1991); furthermore, pigeons are heavily hunted throughout the Philippines, and these three species may well be close to extinction on Negros, with the two Ducula species probably already extinct. Blue-naped Parrot Tanygnathus lucionensis and Blue-backed Parrot T. sumatranus, like Philippine Cockatoo, are heavily trapped throughout their ranges and may be extinct on the island. Gould's Bronze-cuckoo Chrysococcyx 
russatus, Drongo Cuckoo Surniculus lugubris, Common Koel Eudynamys scolopacea, Variable Dwarf-kingfisher Ceyx lepidus, Indigo-banded Kingfisher Alcedo cyanopectus, Hooded Pitta Pitta sordida, White-browed Shama Copsychus luzoniensis, Philippine Leaf-warbler Phylloscopus olivaceus, Lovely Sunbird Aethopyga shelleyi and Striped Flowerpecker Dicaeum aeruginosum are all lowland forest species and presumably under considerable threat on Negros, although $A$. cyanopectus and $P$. sordida were both observed to tolerate secondary forest elsewhere in the Philippines (R.J.T. pers. obs.).

\section{Mammals on Negros}

Negros has only six species of large mammal. Long-tailed macaque Macaca fascicularis, leopard cat Felix bengalensis, malay civet Viverra tangalunga and common palm civet Paradoxurus hermaphroditus are widespread in South-East Asia. The only records were of a total of $13 \mathrm{M}$. fascicularis groups (averaging three individuals per group) across Negros and a single $V$. tangalunga at Mambucal. Negros also has two threatened large mammals (IUCN 1988). The status of bats, based on the results of live-trapping during this expedition, will be discussed in Evans et al. (in prep.).

\section{Philippine spotted deer Cerous alfredi}

In a recent review, Oliver et al. (1991) indicate the dire state of this species in the wild: it is listed as Endangered in IUCN (1988). Oliver et al. (1991) give just five locations for the species: Mt Baloy-Mt Madja-as in western Panay, and sites in northern, central, western and southern Negros.

These small populations are presently under severe pressure from hunting and from trapping for the pet trade. Our survey suggests that the species may be slightly more widespread than Oliver et al. (1991) suggest, but nevertheless to be limited to a few very small populations. It was not directly recorded, but local reports indicate that it persists on Mt Canlaon, Mt Mandalagan (and hence presumably Mt Silay also), in the Cuernos de Negros range, and near Hinob-an in south-west Negros. Patag villagers reported that $C$. alfredi was occasionally seen until a landslide blocked the path to the sulphur springs, and one was apparently caught near the village in a trap in December 1991. A "master hunter" from Mambucal also claimed to have seen $c .50$ C. alfredi on Canlaon in late 1991 (D. Balbin in litt. 1992).

Oliver et al. (1991) argue that in order for the species to be preserved the current captive-breeding programme in Mulhouse Zoo, Germany, and in Dumaguete, Negros, should be supported by the establishment of a national park in western Panay. The remaining Negros populations of the species, however, should not be ignored: enforced preservation of the forest in either the Cuernos de Negros mountains or in the northern Negros range may yet save the species on the island.

Visayan warty pig Sus (barbatus) cebifrons

Cox (1987) showed that $S$. (b.) cebifrons still occurs in remnant populations across 
the Visayas, with viable populations probably surviving on Samar, Leyte, Negros and Panay. Although in less danger than $C$. alfredi, the range of this taxon is contracting rapidly owing to overhunting and habitat destruction. It is sometimes treated as a full species.

Most forests of any size on Negros are likely to retain this species. We saw two groups: four at 1,300 $\mathrm{m}$ at Guintubdan, and three at $900 \mathrm{~m}$ at Mambucal. Local reports were received of the species at every site visited, although at all sites it is apparently heavily hunted. Conservation should consist of forest protection combined with rigidly enforced hunting control.

\section{Conclusions and recommendations}

Of the I90 species of bird resident on Negros about 100 are effectively dependent on forest. Of these, the majority do not occur in high-altitude montane and mossy forest, or only occur in such habitat at low densities. If current rates of deforestation continue, these will be the only forest types to survive on Negros in the near future.

Of the 100-odd resident forest birds on Negros, 59 are endemic to the Philippines. Nine of these are further restricted to the Western Visayas faunal region. In the light of the extensive deforestation which has left the islands of Guimaras and Masbate completely denuded, this means that they are found only on Negros and/or Panay. All of these species are considered to be globally threatened by the clearance of their forest habitat, with specific threats such as the hunting and trapping of pigeons compounding the problem.

Regional and global biodiversity is further threatened by the potential loss of the 26 forest-dependent subspecific taxa endemic to the Western Visayas. Furthermore, twelve non-endemic birds listed by Collar and Andrew (1988) are resident on Negros, and the local extinction of these species would adversely affect both regional biodiversity and the species' global population levels: Muscicapa randi and Erythura viridifacies, for example, would be restricted to Luzon alone if lost from Negros. The two species of ungulates found wild on Negros are also endemic to the central Philippines and globally threatened by deforestation.

To prevent these wholesale extinctions, immediate measures must be implemented. Above all, the effort of international conservation organizations, local NGOs and the national, provincial and community DENR offices should be directed at preserving the remaining forest on the island. The new IPAS project represents an excellent opportunity for this to be organized, and we strongly recommend that Mt Canlaon and the Cuernos de Negros, at least, are considered for inclusion under IPAS. Money should be allocated for such protection above all other conservation schemes, including reforestation projects. Kaingineros should be relocated and illegal logging halted. At several sites we noted the marking of trees for potential future commercial logging, but such logging would be in direct conflict with official commitments to preserve genetic diversity.

The allocation of greater official manpower to the field at all sites would be of much value in deterring kaingineros and raising the sympathy of local people. This could be further enhanced by the adoption of a conservation figurehead, 
maybe Aceros waldeni. Reforestation projects should limit their efforts to areas where forest has already been cleared, and should consider the use of mixed plantations of native species to enhance their value to wildlife.

Finally, conservation strategies for Negros should take into account the particular factors specific to each location. The remaining forest at Ban-ban is of immediate conservation priority for the preservation of Rhinomyias albigularis, and this should perhaps involve physical protection through fencing of the area where the species survives. The responsibilities of PNOC to protect the valuable watershed forest of Cuernos de Negros should be enforced, with the company urged to take an active interest in conservation, particularly of Stachyris nigrorum. The intensive butterfly- and invertebrate-collecting practised in Mt Canlaon National Park should be evaluated and possibly controlled to ensure that the species are not being over-exploited. Further field surveys should be carried out in the Mt Mandalagan and Mt Patag area, in the Hinob-an locality in south-west Negros, and especially in the Cuernos de Negros.

If these recommendations are carried out without delay, it is possible that even the most endangered species remaining on Negros, Rhinomyias albigularis and Gallicolumba keayi, can be saved from global extinction; it is even possible that Ptilinopus arcanus survives and can be preserved. If effective action is not taken very rapidly, eight of the ten species of bird now restricted to Negros or Panay will become extinct by the mid-twenty-first century.

\section{Acknowledgements}

We owe a great debt to those people in the Philippines who worked hard smoothing out the various obstacles for us and for making our time so productive. In particular, our gratitude goes to Carlo Custodio (Head, Wildlife Division, PAWB), Tim Fisher, Dr Pedro Gonzales (Head of Zoology, National Museum), The Haribon Foundation, Arne Jensen (ICBP-Philippines), Dr Frank Lambert (ICBP/IUCN) and Samuel Penafiel (Director, PAWB) in Manila; to Jardine Davis (Philippines) Inc in Manila (Tim Bennett and Simon Michael) and Bacolod City (Alex Poras and Tony Go); to Perla Magsalay (National Co-ordinator) and the staff of the AWB-Philippines on Cebu, Siquijor and Olango Island; to the Chairman, Leonardo Gabutero and volunteers of the Kalikasan Mindoro Foundation, particularly Samson and Efraim Tejada, in San Jose, Mindoro; and to the numerous DENR staff at PENRO and CENRO offices, particularly the local directors, who accommodated, advised and aided us. Among the latter, Mila Ebreo (llo Ilo, Panay), Dodo Balabin (Bacolod City), Chamberlin Babiera (Dumaguete City) and Vivencio Mitra (Sablayan, Mindoro) proved particularly knowledgeable and keen to help in the fieldwork - we wish them all success in the future.

Thanks also to our many advisors in the U.K. and U.S.A., in particular Gary Allport (ICBP), Dr Roger Cox, Finn Danielsen (Danish Ornithological Society), Edward Dickinson (who kindly donated six copies of Dickinson et al. [1991]), Ian Hartley, Rod Hall, Professor Laurence Heaney, Dr Robert Kennedy, Ben King and Dr William Oliver. Most of all, our appreciation goes to those who supported us financially. We are extremely grateful to Bio-science Supplies; Mrs Bowie FLS; British Airways-Assisting Nature Conservation; British Ecological Society; A. S. Butler Charitable Trust; Cambridge Expeditions Fund; Camlab Ltd; Cotton Trust; D. M. Charitable Trust; Douglas Heath Eves Charitable Trust; $\mathrm{Mr}$ and Mrs Dutson; Emmanuel College, Cambridge; Evans + Langford; Mr and Mrs Evans; Russell and Mary Foreman 1980 Charitable Trust; Gilchrist Educational Trust; Godinton Charitable Trust; Hawkins and Manwaring; H. E. Durham Fund; J. Saville 
Gordon Ltd; J. Wilson and Sons (Kendal) Ltd; Jardine Davis (Philippines) Inc; Jesus College, Cambridge; John West Foods Ltd; Laing's Charitable Trust; Memtek; New York Explorer's Club Youth Activity Fund; Oriental Bird Club; Rayne Foundation; Rob Thompson Memorial Fund; Robin Johnson Design Ltd; Royal Geographical Society (Barday's Bank); Selwyn College, Cambridge; St John's College, Cambridge; Tate and Lyle; Walkers Shortbread; Wall Charitable Trust; Wellconstruct Trust; Mrs C. Willets; Mr G. S. Willets; Mr J. D. Willets; Wolverhampton Anglo-Netherlands Society; and to the Cambridge Student Birders and all of the generous Bird Race sponsors, especially the Carphone Warehouse.

\section{Appendix. Total bird-days at each site for all resident species known from Negros.}

All forest species resident on Negros are listed below ${ }^{1}$. Taxonomy follows Sibley and Monroe (1990), while English names and systematic order follow Dickinson et al. (1991). The total numbers of bird-days recorded by all observers is given for all sites. This is clearly very dependent on the time spent in the field (see Table 3) and on the physical structure of the habitat. Birds for which convincing local reports were given are marked with $r$; + indicates presence of a species which is impossible to count. Philippine endemics are capitalized.

Site 1, Guintubdan, Mt Canlaon NP; Site 2, Mambucal, Mt Canlaon NP; Site 3, Mt Mandalagan; Site 4, Ban-ban; Site 5, Balinsasayao; Site 6, Mt Talinis. The final column shows the total records on Negros.

\begin{tabular}{|c|c|c|c|c|c|c|c|}
\hline \multirow[t]{2}{*}{ Species } & \multicolumn{7}{|c|}{ Site } \\
\hline & $I$ & 2 & 3 & 4 & 5 & 6 & Negros \\
\hline \multicolumn{8}{|l|}{ Malayan Night-heron Gorsachius melanolophus } \\
\hline $\begin{array}{l}\text { Oriental Honeybuzzard Pernis ptilorhynchus } \\
\text { Barred Honeybuzzard } P \text {. celebensis }\end{array}$ & 1 & 2 & 2 & 2 & & & 7 \\
\hline White-bellied Sea-eagle Haliaeetus leucogaster & & & & & 1 & & $\mathbf{x}$ \\
\hline Philippine Serpent-eagle Spilornis holospilus & & 6 & 2 & 3 & 1 & 1 & 13 \\
\hline Besra Accipiter virgatus & 3 & 3 & 2 & 2 & 3 & & 13 \\
\hline \multicolumn{8}{|l|}{ Crested Goshawk A. trivirgatus } \\
\hline Rufous-bellied Eagle Hieraaetus kienerii & & & & & 1 & & $\mathbf{1}$ \\
\hline PHILIPPINE HAWK EAGLE Spizaetus philippensis & & 2 & & & 1 & 1 & 4 \\
\hline PHILIPPINE FALCONET Microhierax erythrogenys & & & & 21 & & & 21 \\
\hline Tabon Scrubfowl Megapodius cumingii & & & $\mathbf{r}$ & $\mathbf{r}$ & & & $\mathbf{r}$ \\
\hline $\begin{array}{l}\text { Red Junglefowl Gallus gallus } \\
\text { Pompadour Green-pigeon Treron pompadora }\end{array}$ & 5 & 1 & & 5 & 1 & & 12 \\
\hline $\begin{array}{l}\text { WHITE-EARED BROWN-DOVE Phapitreron leucotis }{ }^{2} \\
\text { AMETHYST BROWN-DOVE P. amethystina }{ }^{2}\end{array}$ & 33 & 65 & 12 & 17 & 56 & 2 & 185 \\
\hline $\begin{array}{l}\text { YELLOW-BREASTED FRUTT-DOVE Ptilinopus occipitalis }{ }^{3} \\
\text { BLACK-CHINNED FRUIT-DOVE } P \text {. leclancher }{ }^{3} \\
\text { NEGROS FRUIT-DOVE } P \text {. arcanus }\end{array}$ & 6 & 48 & 15 & 3 & 23 & & 95 \\
\hline $\begin{array}{l}\text { PINK-BELLIED IMPERIAL-PIGEON Ducula poliocephala } \\
\text { Green Imperial-pigeon } D \text {. aenea }\end{array}$ & 1 & 14 & 9 & 14 & 16 & & 54 \\
\hline $\begin{array}{l}\text { SPOTTED IMPERIAL-PIGEON D. carola } \\
\text { Pied Imperial-pigeon } D \text {. bicolor }\end{array}$ & & & & & & & \\
\hline Metallic Pigeon Columba vitiensis & 27 & & 1 & & 1 & & 29 \\
\hline Reddish Cuckoo-dove Macropygia tenuirostris & 9 & 9 & 2 & 23 & 11 & & 54 \\
\hline Common Emerald-dove Chalcophaps indica & & 3 & & 9 & & & 13 \\
\hline NEGROS BLEEDING-HEART Gallicolumba keayi & $\mathrm{r}$ & $1 \mathrm{r}$ & $\mathbf{r}$ & & & & $1 \mathrm{r}$ \\
\hline
\end{tabular}


Appendix. (cont.)

\begin{tabular}{|c|c|c|c|c|c|c|c|}
\hline \multirow[t]{2}{*}{ Species } & \multicolumn{7}{|c|}{ Site } \\
\hline & $\mathbf{1}$ & 2 & 3 & 4 & 5 & 6 & Negros \\
\hline $\begin{array}{l}\text { BLUE-HEADED RACQUET-TAILED PARROT Prioniturus } \\
\text { discurus }\end{array}$ & & 87 & & 9 & & & 98 \\
\hline \multicolumn{8}{|l|}{ Blue-naped Parrot Tanygnathus lucionensis } \\
\hline \multicolumn{8}{|l|}{ Blue-backed Parrot $T$. sumatranus } \\
\hline PHILIPPINE HANGING-PARROT Loriculus philippensis & & $1^{4}$ & & & & & $\mathbf{1}$ \\
\hline \multicolumn{8}{|l|}{ Hodgson's Hawk-cuckoo Cuculus fugax } \\
\hline Rusty-breasted Cuckoo C. sepulcralis & & 6 & 1 & & & & 7 \\
\hline \multicolumn{8}{|l|}{ Gould's Bronze-cuckoo Chrysococcyx russatus } \\
\hline \multicolumn{8}{|l|}{ Drongo Cuckoo Surniculus lugubris } \\
\hline \multicolumn{8}{|l|}{ Common Koel Eudynamys scolopacea } \\
\hline PHILIPPINE COUCAL Centropus viridis & 1 & 30 & & 3 & 5 & & 39 \\
\hline \multicolumn{8}{|l|}{ PHILIPPINE SCOPS-OWL Otus megalotis } \\
\hline \multicolumn{8}{|l|}{ Brown Hawk-owl N. scutulata } \\
\hline PHILIPPINE HAWK-OWL Ninox philippensis & 5 & 8 & 3 & 3 & 6 & & 25 \\
\hline PHILIPPINE FROGMOUTH Batrachostomus septimus & 2 & & & & & & 2 \\
\hline \multicolumn{8}{|l|}{ Great Eared-nightjar Eurostopodus macrotis } \\
\hline \multicolumn{8}{|l|}{ Philippine Nightjar Caprimulgus manillensis } \\
\hline Whiskered Treeswift Hemiprocne comata & 3 & 7 & & $\mathbf{I}$ & 3 & & 14 \\
\hline PHILIPPINE SWIFTLET Collocalia mearnsi & + & + & + & + & & + & + \\
\hline Glossy Swiftlet C. esculenta & + & + & + & + & + & + & + \\
\hline PYGMY SWIFTLET C. troglodytes & & + & + & + & + & + & + \\
\hline PHILIPPINE SPINETAIL Mearnsia picina & 8 & & & & $\mathbf{1}$ & 3 & 12 \\
\hline Purple Needletail Hirundapus celebensis & 3 & 86 & 73 & 29 & 19 & 27 & 237 \\
\hline
\end{tabular}

INDIGO-BANDED KINGFISHER Ceyx cyanopectus

Variable Dwarf-kingfisher $C$. lepidus

RUFOUS-LORED KINGFISHER Halcyon winchelli

SPOTTED WOOD-KINGFISHER Actenoides lindsayi

Dollarbird Eurystomus orientalis

VISAYAN TARICTIC HORNBILL Penelopides panini

WRITHED-BILLED HORNBILL Aceros waldeni

Coppersmith Barbet Megalaima haemacephala

White-bellied Woodpecker Dryocopus javensis

PHILIPPINE PYGMY WOODPECKER Dendrocopos

maculatus

Greater Flameback Chrysocolaptes lucidus

Red-bellied Pitta Pitta erythrogaster

Hooded Pitta P. sordida

Bar-bellied Cuckoo-shrike Coracina striata

WHITE-WINGED CUCKOO-SHRIKE C. ostenta

Scarlet Minivet Pericrocotus flammeus

PHILIPPINE BULBUL Hypsipetes philippinus

BALICASSIAO Dicrurus balicassius

PHILIPPINE ORIOLE Oriolus steerii

ELEGANT TIT Parus elegans

Sulphur-billed Nuthatch Sitta oenochlamys

STRIPE-HEADED RHABDORNIS Rhabdornis mystacalis

PLAIN-HEADED RHABDORNIS $R$. inornatus

FLAME-TEMPLED BABBLER Stachyris speciosa

NEGROS STRIPED-BABBLER $S$. nigrorum

White-browed Shortwing Brachypteryx montana

WHITE-BROWED SHAMA Copsychus luzoniensis

Sunda Ground-thrush Zoothera andromedae ${ }^{5}$

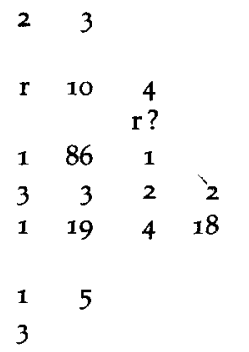


Appendix. (cont.)

\begin{tabular}{|c|c|c|c|c|c|c|c|}
\hline \multirow[t]{2}{*}{ Species } & \multicolumn{7}{|c|}{ Site } \\
\hline & $\mathbf{1}$ & 2 & 3 & 4 & 5 & 6 & Negros \\
\hline $\begin{array}{l}\text { Island Thrush Turdus poliocephalus } \\
\text { PHILIPPINE LEAF-WARBLER Phylloscopus olivaceus }\end{array}$ & 65 & 13 & & & & & 78 \\
\hline LEMON-THROATED LEAF-WARBLER $P$. cebuensis & 91 & 192 & 62 & 80 & 32 & 27 & 484 \\
\hline Mountain Leaf-warbler $P$. trivirgatus & 319 & 52 & 45 & & 17 & 52 & 485 \\
\hline PHILIPPINE TAILORBIRD Orthotomos castaneiceps & 20 & 152 & 42 & $7^{8}$ & 71 & 2 & 365 \\
\hline $\begin{array}{l}\text { WHITE-THROATED JUNGLE-FLYCATCHER } \\
\text { Rhinomyias albigularis } \\
\text { ASHY-BREASTED FLYCATCHER Muscicapa randi }\end{array}$ & & & & 6 & & & 6 \\
\hline Mountain Verditer-flycatcher Eumyias panayensis & 62 & 57 & 26 & 5 & 15 & 13 & 178 \\
\hline Snowy-browed Flycatcher Ficedula hyperythra & 16 & 13 & 3 & 2 & 11 & 3 & 48 \\
\hline $\begin{array}{l}\text { Little Pied Flycatcher } F \text {. westermanni } \\
\text { Mangrove Blue Flycatcher Cyornis rufigastra }\end{array}$ & 22 & $\begin{array}{r}15 \\
6\end{array}$ & 7 & & 18 & 4 & $\begin{array}{r}66 \\
6\end{array}$ \\
\hline Citrine Canary-flycatcher Culicicapa helianthea & 97 & 154 & 70 & 50 & 98 & 19 & 488 \\
\hline $\begin{array}{l}\text { BLUE-HEADED FANTAIL Rhipidura cyaniceps } \\
\text { CELESTIAL MONARCH Hypothymis coelestis }\end{array}$ & 183 & 248 & 135 & 174 & 160 & 30 & 930 \\
\hline Black-naped Monarch $H$. azurea & & 9 & 25 & 4 & 4 & & 42 \\
\hline $\begin{array}{l}\text { RUFOUS PARADISE-FLYCATCHER } \\
\text { Terpsiphone cinnamomea }\end{array}$ & & & & 1 & & & $\mathbf{I}$ \\
\hline WHITE-VENTED WHISTLER Pachycephala homeyeri & 17 & 47 & 20 & 67 & 38 & 4 & 193 \\
\hline COLETO Sarcops calvus & 23 & 43 & 7 & 21 & 9 & 20 & 123 \\
\hline Plain-throated Sunbird Anthreptes malacensis & & & & & & & \\
\hline Purple-throated Sunbird Nectarinia sperata & & 2 & 14 & 7 & 7 & & 30 \\
\hline $\begin{array}{l}\text { Flaming Sunbird Aethopyga flagrans } \\
\text { LOVELY SUNBIRD A. shelleyi }\end{array}$ & 2 & 10 & 7 & 3 & 11 & 3 & 36 \\
\hline Crimson Sunbird $A$. siparaja & & $1+$ & & & & & $\mathbf{1}+$ \\
\hline STRIPED FLOWERPECKER Dicaeum aeruginosum & & & & & & & \\
\hline BICOLOURED FLOWERPECKER Dicaeum bicolor & 2 & 52 & 13 & 6 & 13 & 2 & 88 \\
\hline VISAYAN FLOWERPECKER D. (australe) haematostictum & 2 & 6 & 12 & & 1 & & 21 \\
\hline Orange-bellied Flowerpecker $D$. trigonostigma & 23 & 84 & 20 & 27 & 64 & 12 & 230 \\
\hline PYGMY FLOWERPECKER D. pygmaeum & & & & 2 & & 1 & 3 \\
\hline Dicaeum spp. & 53 & 142 & 14 & & $4^{8}$ & 6 & 237 \\
\hline GOLDEN-YELLOW WHITE-EYE Zosterops nigrorum & & 79 & 132 & 13 & 18 & 10 & 252 \\
\hline $\begin{array}{l}\text { Mountain White-eye Z. montanus } \\
\text { GREEN-FACED PARROTFINCH Erythrura viridifacies }\end{array}$ & 1,435 & 740 & 560 & 17 & 32 & 254 & 3,038 \\
\hline
\end{tabular}

1. The only non-resident forest species recorded on Negros of particular conservation interest is Japanese Night-heron Gorgachius goisagi (Rand and Rabor 1960).

2. These totals include aural records. There appeared to be a degree of overlap between the vocalizations of White-eared Brown-dove Phapitreron leucotis and Amethyst Brown-dove P. amethystina.

3. These totals include aural records. There appeared to be a degree of overlap between the vocalizations of Yellow-breasted Fruit-dove Ptilinopus occipitalis and Black-chinned Fruit-dove $P$. leclancheri.

4. Our only record of Philippine Hanging-parrot Loriculus philippensis was one hanging dead from a hunter's belt at $\mathrm{c} .950 \mathrm{~m}$ at Mambucal.

5. There has been only one previous Negros record of Sunda Ground-thrush Zoothera andromedae, at Balinsasayao (Erickson and Heideman 1983).

6. Erickson and Heideman (1983) claim a record of Olive-backed Flowerpecker Prionochilus olivaceus, netted in forest edge at Balinsasayao. P. olivaceus is restricted to the eastern Philippines and not known from Negros; presumably this is a misprint for Philippine Leaf-warbler Phylloscopus olivaceus. 


\section{References}

Alcala, A. C. and Carumbana, E. E. (1975) An ecological study of certain game birds in southern Negros Oriental, Philippines. NRCP Res. Bull. 30: 91-119.

Alcala, A. C. and Carumbana, E. E. (1980) Ecological observations on birds of southern Negros, Philippines. Silliman J. 27: 163-178.

Alcala, A. C. and Sanguila, W. M. (1969) The birds of small islands off the eastern coast of Panay. Silliman J. 27: 197-222.

Andrew, P. and Holmes, D. A., compilers. (1990) Sulawesi bird report. Kukila 5: 4-26.

Collar, N. J. and Andrew, P. (1988) Birds to watch: the ICBP world checklist of threatened birds. Cambridge, U.K.: International Council for Bird Preservation (Techn. Publ. 8).

Clarke, T. (1983) Unpublished report on a birdwatching trip to the Philippines.

Cox, C. R. (1987) The Philippine Spotted Deer and the Visayan Warty Pig. Oryx 21: 3742.

Delacour, J. and Mayr, E. (1946) Birds of the Philippines. New York: Macmillan.

Dickinson, E. C., Kennedy, R. S. and Parkes, K. C. (1991) The birds of the Philippines. London: British Ornithologists' Union (Check-list 12).

DuPont, J. E. (1971) Philippine birds. Grenville, Delaware: Delaware Museum of Natural History.

Dutson, G. C. L., Evans, T. D., Brooks, T. M., Asane, D. C., Timmins, R. J. and Toledo, A. G. (1992) Conservation status of the birds on Mindoro, Philippines. Bird Conserv. Internat. 2: 303-325.

Erickson, K. R. and Heideman, P. D. (1983) Notes on the avifauna of the Balinsasayao rainforest region, Negros Oriental, Philippines. Silliman J. 30: 63-70.

Evans, T. D., Magsalay, P., Dutson, G. C. L. and Brooks, T. M. (in press) Conservation status of forest birds on Siquijor, Philippines. Forktail.

Evans, T. D., Dutson, G. C. L. and Brooks, T. M., eds. (in prep.) Final report of the Cambridge Philippines Rainforest Project 1991.

Gibbs, D. (1983) Unpublished report on a birdwatching trip to the Philippines.

Goodwin, D. (1983) Pigeons and doves of the world. Ithaca, New York: Cornell University Press.

Hornskov, J. and Jensen, S. (1987) Unpublished report on a birdwatching trip to the Philippines.

ICBP (1992) Putting biodiversity on the map: priority areas for global conservation. Cambridge, U.K.: International Council for Bird Preservation.

IUCN (1988) The red list of threatened mammals. Cambridge, U.K.: World Conservation Monitoring Centre.

Jensen, A. (in prep.) Final report of the ICBP-DAFIF Palawan Expedition 1991.

Kemp, A. C. (1988) The systematics and zoogeography of Oriental and Australasian hornbills (Aves: Bucerotidae). Bonn. zool. Beitr. 39: 315-345.

King, B. F. (1983) Unpublished report on a birdwatching trip to the Philippines.

Lambert, F. R. (1992) The population size, distribution and ecology of the Philippine Cockatoo Cacatua haematuropygia. Unpublished report to IUCN/SSC and CITES Secretariat.

Lewis, I. (1991) Unpublished report on a birdwatching trip to the Philippines.

McGregor, R. C. (1909-1910) A manual of Philipphine birds. Manila: Bureau of Science.

McGregor, R. C. (1920) Some features of the Philippine ornis with notes on the vegetation in relation to the avifauna. Philippine J. Sci. 16: 361-437.

Mayr, E. (1957) New species of birds described from 1941 to 1955. J. Orn. 98: 22-35.

Ogilvie Grant, W. R. (1896) On the birds of the Philippine Islands - Part VIII. The highlands of Negros. Ibis 2(7): 525-565.

Oliver, W. L. R., Cox, C. R. and Dolar, L. L. (1991) The Philippine Spotted Deer Conservation Project. Oryx 25: 199-205. 
Parkes, K. C. and Dickinson, E. C. (1991) Types, type localities and variation in some races of the Colasisi or Philippine Hanging Parrot Loriculus philippensis. Bull. Brit. Orn. Club 111: 104-109.

Rabor, D. S. (1954) New bird records on Negros Island, Philippines. Silliman J. 1: 77-82.

Rabor, D. S. (1977) Philippine birds and mammals. Diliman, Quezon City, Philippines: University of the Philippines Press.

Rabor, D. S., Alcala, A. C. and Gonzales, R. B. (1970) A list of the land vertebrates of Negros Island, Philippines. Silliman J. 17: 297-316.

Rand, A. L. (1951) Birds of Negros Island. Fieldiana Zool. 31(48): 571-596.

Rand, A. L. (1954) Birds of the Balinsasayao Lakes in the Philippines. Bull. Chicago Nat. Hist. Mus. Feb.: 4-5, 8.

Rand, A. L. and Rabor, D. S. (1952) Notes on Philippine birds. Nat. Hist. Misc. 107: 1-5.

Rand, A. L. and Rabor, D. S. (1960) Birds of the Philippine Islands: Siquijor, Mount Malindang, Bohol, and Samar. Fieldiana Zool. 35(7): 221-441.

Ripley, S. D. and Rabor, D. S. (1955) A new fruit pigeon from the Philippines. Postilla 21.

Ripley, S. D. and Rabor, D. S. (1956) Birds from Canlaon Volcano in the highlands of Negros Island in the Philippines. Condor 58: 283-291.

Rozendaal, F. G. and Dekker, R. W. R. J. (1989) An annotated checklist of the birds of the Dumoga-Bone National Park, North Sulawesi. Kukila 4: 85-109.

Sibley, C. G. and Monroe, B. L. (1990) Distribution and taxonomy of birds of the world. New Haven and London: Yale University Press.

SSC [Swedish Space Corporation] (1987) Land cover maps of the Philippines. 1:250 000.

SSC [Swedish Space Corporation] (1988) Mapping of the natural conditions of the Philippines. Final Report, 30 April 1988.

Turton, J. M., Speight, G. and Rowland, R. (1986) Unpublished report on a birdwatching trip to the Philippines.

Vaurie, C. (1952) A review of the bird genus Rhinomyias (Muscicapini). Amer. Mus. Novit. 1570.

Whitten, A. J., Mustafa, M. and Henderson, G. S. (1987) The ecology of Sulawesi. Yogoyakarta, Indonesia: Gadja Mada University Press.

Wolters, H. E. (1980) Die Vogelarten der Erde. Hamburg: Paul Parey.

THOMAS M. BROOKS

Emmanuel College, Cambridge $C B_{2}{ }_{3} A P, U . K$.

TOM D. EVANS

11a Yeoman Lane, Bearsted, Maidstone, Kent ME14 4BX, U.K.

GUY C. L. DUTSON

Selwyn College, Cambridge $\mathrm{CB}_{3}{ }_{9} D Q, U . K$.

GUY Q. A. ANDERSON

Horsewells, Drumoak, Banchory, Kincardineshire $A B_{31}{ }_{3} E R, U . K$.

DESIDERIO C. ASANE

Asian Wetland Bureau, Unit 2, A. Sing Building, Duterte Street, Banawa, Cebu 60oo, Philippines.

ROBERT J. TIMMINS

25 Cradley Road, Cradley Heath, Warley, West Midlands B64 6AG, U.K.

ANGELA TOLEDO

148-E Gorordo Avenue, Lahug, Cebu 60oo, Philippines. 